\title{
ISLAMIC PERFORMANCE INSTRUMENT (IPI): AN ALTERNATIVE SERVANT LEADERSHIP (SL) TOOL FOR SUSTAINABLE DEVELOPMENT GOALS (SDGS)
}

\author{
Kazeem Olanrewaju Ogunsola ${ }^{*}$, Suhaimi Mhd Sarif ${ }^{2}$, Rodrique Ancel ot Harvey Fontaine ${ }^{3}$ \\ *Corresponding Author \\ ${ }^{1}$ Department of Business Administration, Kulliyyah of Economics and Management Sciences, International Islamic \\ University Malaysia, Jalan Gombak, 53100, Selangor, Malaysia,qmasjid@yahoo.com. \\ ${ }^{2}$ Department of Business Administration, Kulliyyah of Economics and Management Sciences, International Islamic \\ University Malaysia, Jalan Gombak, 53100, Selangor, Malaysia, suhaimims@iium.edu.my \\ ${ }^{3}$ Kulliyyah of Economics and Management Sciences, International Islamic University Malaysia, 53100, Selangor, Malaysia, \\ ridhwan_fontaine@iium.edu.my
}

\begin{abstract}
In the search for measures to keep the society sustained, a qualitative study was conducted to explore a Tawhidic Paradigm (TP) alternative for servant leaders, building upon Greenleaf servant leadership (SL) theory. The aim is to ground an Islamic Performance Instrument (IPI) favourable to sustainable development (SD). Adopting Charmaz's (2006) constructivist Grounded Theory Method (GTM), 5 Muslim managers were identified and interviewed through purposive sampling. The coding process produced an IPI-5es principles (expertise, ethereal, emotional, ethical and empowering) essentially required by servant leaders to transform SDGs around the globe. The Islamic constructs of 'Aqidah (Creed), Khalifa (Vicegerent) and 'Adl (Justice) were critical in grounding these principles. Theoretically, the research outcome contributes to body of knowledge on Tawhidic Paradigm (TP) and Islamic Servant Leadership (ISL). This paper projects leaders forming polices that synchronizes meeting SDGs with spiritual responsibilities. Practically, it offers leaders the ideal purpose of SL: servitude to the Creator - (Allah) and, also to humanity (fulfilling SDGs), as against the conventional SL theory which excludes the former. By implication, TP projects service to humanity (SDGs) as acts of worship (Ibadah). The paper was limited by fewer GTM research on Islamic SL principles for SDGs. Future study may conduct a time series analysis on servant leaders imbued with IPI-5es principles to determine SDGs success rate. The paper offers a pioneer model (IPI-5es principles) that extends conventional SL theory for SD.
\end{abstract}

Keywords: Sustainable development goals (SDGs), Islamic performance instrument (IPI), Servant leadership (SL), Islamic servant leadership (ISL), Tawhidic paradigm (TP), Grounded theory method (GTM)

Received

Revised

January 2, 2020

February 22, 2020

Accepted

Published

March 4, 2020

March 31, 2020

\section{INTRODUCTION}

"Humanity needs Islamic law: "The law of the Qur'an will prevail in the world because it agrees with reason and wisdom. I have come to understand that humanity needs only a Divine law to establish the truth and destroy falsehood. Islamic law will encompass the entire world because it is consistent with reason and agrees with wisdom and justice." Leo Tolstoy (1828 - 1910)

The opening excerpt vividly suggests a retrace to spiritual governance in order to salvage human race or what campaigners of the 21 st century refer to as "sustainable development" (SD). Either way this is phrased, the religion of Islam is firmly established to stand the test of time on human evolution. Ironically, the previous decades have been polarized with governance or leadership theories that have alienated leaders - the presumed custodian of 'human, earth and its resources' - from their spiritual functions. Hence, 
leadership roles have been structured with little or no thoughtfulness of its effects on future generations.

The most recent leadership theory, servant-Leadership (SL), by Robert K. Greenleaf is promising except for its lack of Islamic constructs, which Muslim researchers(e.g., Khaliq \& Fontaine, 2013; Khaliq \& Ogunsola, 2011; Sarif, 2014)often refer to as Tawhidic Paradigm (TP). This shortcoming portends a breach of Allah's ordained responsibilities on leaders. Perhaps, such breach may have been responsible for dwindling sustainable growth, as most leaders are self-consumed and do not see themselves accountable to a Supreme Being (Allah).Gupta and Agrawal (2017) posit it that sustainable development guarded by spirituality helps to revere nature as scared and dominant over material expectations.

Governance in Islam is regimented, suggesting that leadership activities should be within the confine stipulated by the Shariah law (Alwazna, 2016). Ismail and Tohirin (2010)argued that the Islamic law encompasses set of regulations to safeguard individuals from arbitrary use of power, position or resources. Al-Attas and Daud (2007) posit that governance built on TPfocuses on 'pre-life, life and after-life' of human existence. Hence, sustainable development growth is naturally ingrained in Islam.

In other narratives (e.g., Y. Ismail \&Sarif, 2011), it was argued that TP bridges the relationship between Allah and human beings, human beings and human beings, and human beings with other creatures. Therefore, TP is envisioned as a multi-function SL concept that embodies mundane (worldly) and spiritual tasks: i.e., a duty towards the worship of Allah, duty towards oneself, and duty towards nature (other creatures of Allah, the living [e.g. human, animal and plants] or the non-living e.g. earth and its resources). This concept till date is alien to conventional leadership theories.

Given the exigency to salvage the continued deterioration of Allah endowed resources on human race or the call for sustainable development, much is expected from its custodians (e.g., leaders). Realigning existing SL theories with Islamic constructs (Tawhidic paradigm) may project a better performance towards attaining SDGs. In view of this, an Islamic Performance Instrument (IPI) is expectedly required to capture the nitty-gritty of leadership responsibilities.

\section{LITERATURE REVIEW}

\section{Leadership}

Leadership is an age-century terminology (Conger \& Kanungo, 1987; Stogdill, 1975). Being a research field and a form of practical skill, leadership has received multiplicity of definitions (Rost, 1993; Zhao \& Li, 2019). In three words, Summerfield (2014) briefly explained that the core function of leadership is to "make things better" (p. 252). Hence, it is about creating positive change for common good (Dinh \& Lord, 2012) or expression of cognitive skills to solve collective problems (Pietraszewski, 2019) towards an improved state of being. This paper defines it as a dynamic process built upon mutual relationship to achieve a common purpose. So, in the context of SD, leaders are presumed as social architect whose function is to inspire shared vision, promote equity and advocate for empowerment.

In spite of the many theories on leadership (Hoch et al., 2016; Meuser et al., 2016), emerging developments often necessitate scholars to propose new concepts and theories 
intermittently (Zhao \& Li, 2019). Perhaps, due to criticisms (Dinh et al., 2013; Judge \& Piccolo, 2004; Price, 2003; Spoelstra et al., 2016) or theory inadequacy (Alvesson \& Einola, 2019; Bass, 2008). There are also claims that demise of the advocates of some of leadership theories (e.g., charismatic leadership theory) led to their research decline (Antonakis et al., 2014; Zhao \& Li, 2019). Other researchers (e.g., McCleskey, 2014; Nicholls, 1985) mentioned that theory like situational leadership has consistency, continuity, conformity and ambiguity issues.

Studies equally revealed that leaders often exploit Maslow (1943) hierarchy of needs by presenting subordinates with these needs (transactional) to get them perform some tasks (Burns et al., 2015; Dartey-Baah, 2014; McCleskey, 2014). This implies that some leadership theories are goal-oriented, not people-oriented (Judge \& Piccolo, 2004). Though, there are positive arguments for goal-oriented leadership; still, it can be detrimental (Hargreaves \& Fink, 2003). Dartey-Baah (2014) argued that goal-oriented leadership can make leaders "take to any means to achieve their set targets, even when these means are unethical and unstainable" (p. 206).

In view of these claims and counterclaims, McCleskey (2014) suggests having an imperative understanding of which theory is essentially needed to achieve effective leadership. This understanding is becoming more striking in the light of some contemporary leadership challenges such as the call to leaders to meet 2030 SDGs.

\section{Sustainable Development}

Sustainability is the practice of maintaining world processes of productivity indefinitely (Lynn \& Kahle, 2014). So, the most widely accepted definition for SD is referred to as "a development process that meets the needs of the present without compromising the ability of future generations to meet their own needs" (WCED, 1987 p.43). It is a concept of present generation being responsible to regenerate, maintain and improve planetary resources for use by future generations(Finn, 2009; Kumar, 2017). Impliedly, SD is framed on the domains of ecology, economics, politics and culture (Magee et al., 2013; Zelenika \& Pearce, 2014).

Basically, SD assumptions focus on the "integrational concept of meeting human needs" (Gupta \& Agrawal, 2017 p. 1923) by "maximizing the net benefits of economic evolution, subject to maintaining the services and quality of natural resources over time" (Pearce \& Turner, 2009 p. 24). Hence, it is about maintaining a balance, both in present society and over time (Bedsworf \& Hanak, 2010; Dahl, 1996). How this recent terminology relates to leadership is the nitty-gritty of the current paper.

\section{Contemporary Leadership Challenges}

In September 2015, the United Nations General Assembly formally adopted the "2030 Agenda for Sustainable Development" (Galli et al., 2018) which provided a "universal, integrated and transformative" blueprints of 17 Sustainable Development Goals (SDGs) to be implemented and achieved in every country (Wulf et al., 2018). The goals require urgent call for action(Fitchett \& Atun, 2014), as such, are potential contemporary challenges for leaders to meet in order to keep the society sustained.

It posits that apart from their traditional corporate responsibilities (Kouzes \& Posner, 2007; McCleskey, 2014), leaders are now required to take broader actions on climate change, 
end poverty, hunger and inequality. There is the need to improve environment, access to health care, clean water, quality education and so forth. These goals may not have been on the requisite list of existing leadership theories. However, current phenomenon reveals to a large extent that leaders have a great role to play in sustaining the $21^{\text {st }}$ century society (Dartey-Baah, 2014; Martiskainen, 2017).

Even a cursory look at the definitions of SD portends a connection between it and leadership. This is because development and leadership run concurrently(Slimane, 2012), hence, there is no development without leadership. More so, achieving SDGs require the concerted effort of leaders in respective sectors (Bahauddin, 2018) such as government, business, society or at individual level. For instance, Kilpinen and Clarkson (2009)discussed that SD is a complex and multifaceted concept such that politicians view it in terms of community projects, businesses perceive it as sustained goods and profit, the environmentalists regard it as efficient use of natural resources, and the masses consider it as a means to meet their needs and eradicate poverty. Other studies (e.g., Dartey-Baah, 2014; Sherman, 2019) have equally reiterated the importance of leadership intervention in a system to change its status-quo and shift it towards sustainability.

Therefore, to solve the $21^{\text {st }}$ century SD challenges, SL theory is primed asappropriate because of its focus on service to humanity. Researchers (e.g., Cooper \& Nirenberg, 2012) are of the opinion that effective leaders can be viewed from social perspective such that successful leadership results in accomplishing (community) shared objectives. The 17 SDGs are shared community objectives that needed to be accomplished by every successful leader (Wulf et al., 2018). On this note, it suffices to look into that leadership theory that serves the community, whose tenets deal with social complex problems that involves the interaction between people and environment.

\section{Servant -Leadership (SL) Theory}

Study on SL theory began barely four decades ago. Management literature documents Robert Greenleaf (1977) as the first to coin the theory (Spears, 1995). The theory is a combination of two words, servant and leader. Kim et al.,(2014) defined it as a theory whose "role of leader focuses on doing voluntary work for others with altruistic ethics; makes members, customers, and local communities a priority; and makes a commitment to satisfying their needs" (p. 1154). So, it is a theory centred on delivering public service to meet the needs and aspirations of thesociety.

Researchers support SL theory because it predisposes servant leaders to be distinct in their governance (Gill, 2013; Northouse, 2013).For instance, being attentive to the concerns of their followers, nurture, and empathize with them (Greenleaf, 1977). van Dierendonck (2011) posits that leaders empower and develop people / society through expression of humility, authenticity, and good stewardship. Hence, SL is poised as an affectionate and humanistic theory (Dennis \& Bocarnea, 2005; Russell \& Stone, 2002) that builds a community of individuals who cares for each other.

Though, criticized in some quarters (Bowie, 2000; Whetstone, 2002); still, SL is about the only leadership theory that places premium on healing and people's growth(Spears, 1995, 2002). For these reasons (e.g., humanitarian concept), this paper assents with it as an ideal leadership theory forSD. However, its lack of transcendental (spiritual) principles call for 
concern (Lynch \& Friedman, 2013)for the task at hand. Its lack of spiritual virtues is not a surprise because "historically, spirituality and leadership theories have been worlds apart" (Freeman, 2011 p.120).

Researchers (e.g., Mittal \& Dorfman, 2012; van Dierendonck, 2011)equally concurred that SL is positioned as a secular theory. For instance: Spears (1995) posits that "leaders exist only to serve their followers" (p.100). This viewpoint do not hold for Muslim leaders (Ali, 2009; Mutalib \& Razali, 2012; Ogunsola, 2018).Hence, there is the need to extend the conventional SL with Tawhidic paradigm.

\section{Leadership Styles}

Researchers (Fontaine, Khaliq, \& Oziev, 2017; Khaliq \& Ogunsola, 2011)note that leaders are expected to be positive thinkers and their activities should completely refrain from all such steps as may prove counter-productive. In this view, Beekun and Badawi (1999) identified two basic leadership styles: directive or task-oriented style and participative or employee-oriented style. McShane and Von Glinow (2008)identified four basic styles of leadership - directive style, supportive style, participative style and achievement-oriented style.

Directive or Task-Oriented Style: Leaders with this style instruct and closely supervise their followers to make sure that the tasks are performed to their expectations. They are more concerned with getting the job done rather than with mentoring or coaching followers. They set targets for followers and ensures they adhere strictly to rules.

Supportive or Employee-Oriented: This includes showing mutual trust and respect for subordinate. Leaders express concern for the followers' needs and look after their welfare. They listen to their suggestions and ideas.

Participative style: More like supportive or employee-oriented style. Leaders with participative style of leadership try to involve instead of directingtheir followers. By so doing, they contribute to employee personal growth and increase their motivation. This style could otherwise be called employee involvement. A participative leader put less emphasis on the use of legitimate power.

Achievement-Oriented: A leader with this style set challenging goals for employee and expect them to perform at peak.

Given these styles, Gardner (1999) reiterates that human beings have been ordained with great faculties and qualities which if properly deployed could result in the achievement of miraculous goals like those of the SDGs. However, leadership in Islam provides extra dimensions that positively reinforce the leadership process and result in a greater good for everyone involved in the process. It is trusteeship of Allah, a responsibility given from Him and a service to mankind (Rafiki, 2020).Hence, in Islam, a leader is not free to act as he or she chooses, nor must he submit to the wishes of any group, he or she must act only to implement Allah's laws on earth. Allah say, "And We made them leaders guiding men by Our command and We sentinspiration to do good deeds, to establish regular prayers, and to practice regular charity; and they constantly served Us only" (Surah Al-Anbiya', [21] 73). On this basis, it suffices to look at the relationship between SD, SL, and spirituality.

\section{Relationship between SD, SL and Spirituality}

Leaders may need a re-assessment of their inner state of consciousness as a push for effective SD. This is becoming more striking, because in spite of the huge investment on 
SDGs, there are reports that world is still falling shorts on its achievement targets (Bruce, 2018; Jeff \& Tomicah, 2017). So, are-assessment is essentially needed. Atkisson (2001) wrote "we cannot go, and we cannot stop. We must transform... the only institution that has demonstrated continuity over millennia are religions and spiritual traditions. So, while we must be intensely scientific, our future is also in need of renewed sense of spirituality and the sacred" (p.10).

As a result, Ulluwishewa (2014) advocates looking beyond materialistic conventional paradigm when dealing with SD issues. Bahauddin (2018) mentioned that achieving SD may not be dependent only on mechanistic paradigm. Kumar (2017) posit it that a successful transition from materialistic world to a sustainable world is dicey if the inner development of mankind is not given a priority. The study of Gupta and Agrawal (2017) found that relationship exit between the achievement of SD and spiritual consciousness. Other researchers (e.g., Stillman et al., 2012)argued that the state of mind is framed by inner mental phenomenon than external material phenomenon. All these facts suggest that the crusade on SD should take place with a balance of material as well as non-material (i.e., spirituality) aspect of life.

Unfortunately, the clamour for SD have always excluded spirituality (Bache, 2001), yet, this is the basic value of life that determine social interaction and cohesion (McCuddy \& Pirie, 2007). Dahl (1996) argued that if the society is to remain sustainable, then this basic value cannot be ignored. The sense of spiritual purpose, belief, and virtues are the only motivational tools that could prompt today's wealthier societies to sacrifice their immediate benefits for the good of future generations. This notion is easily championed by individuals who are transcendentally inclined (King \& DeCicco, 2009).

The world is increasingly going materialistic; leaders are compromising for immediate economic / political gains giving little or no cognizant of their actions on future generations. In Salih's(2003) argument, it was made known that the desire (i.e., competition) for shortterm material gains (e.g., economic and natural resources) constitute a major hindrance towards the achievement of SD. So, developing the inner soul through spiritual enrichment (Kumar, 2017), may perhaps fortify those (herein, leaders) running the course of SD with resiliency, flexibility, and adaptivity (Burns et al., 2015)to look beyond the present.

Lack of intrinsic capabilities (i.e., spiritual virtues) to withstand challenges and problems created by our own self (e.g., through competitive race for economic development) is further pushing the society into aggravating poverty, over-exploitation of the planet-earth resources, self-centeredness, and so forth. Hence, there is the loss of ethics and morals which are essentially important to achieve SD (Ulluwishewa, 2014). Ikerd (2008) reasoned that the loss of faith in religion and spirituality resulted in heightened ethical and moral loss. Whereas, a conscious belief in the Divine Being comes with realization of maintaining good relationship with oneself, others, and the environment (Zohar \& Marshall, 2000). It is a belief that leads to the realization of 'being sensitive to the needs of others' - the bedrock of SD.

In retrospect, SD relates to humanity, so also is SL. Spirituality is noted for its vertical (Divine) and horizontal (humanistic) dimension of life. Strikingly, spirituality acts as an antecedent for conscious connectedness, unity, and peace that span across humanity(Emmons, 2000).So, logically, what truly keeps a society sustained is the conscious connection with living and non-living in the society (see Figure 1). With this maxim, aligning 
conventional SL principles with spiritual virtues (i.e., Tawhidic paradigm) may well promotes good governance, encourage conservation of the environment and foster equitable socioeconomic development.

\section{Tawhidic paradigm}

The monotheist nature of Islam positioned Muslimleaders differently from their conventional counterparts. They are considered as both servant of Allah ('abd Allah) and vicegerent of Allah (Khalifah fil ard). Hence, their core values include upholding goodness (al-maruf) and forbiddance of evil (al-munkar) (Ali, 2009; Alwazna, 2016; Jabnoun, 2008; Sarif, 2014). This infers that within the Islamic context, the components of Tawhid are inseparable in the leadership style of Muslims (Egel, 2014; Ogunsola, 2018).

Tawhidic paradigm (TP) is fundamentally modelled on Islamic-driven constructs. In this paper, the constructs of 'Aqidah (Islamic creed), Khalifa (vicegerent) and 'Adl (justice) are re-aligned with the conventional SL theory for the purpose of SD. Egel (2014)argued that uplifting individual spiritual consciousness helps more to achieve organizational goals and sustainability. Hence, these constructs are Shariah-driven, if properly implemented by leaders, offers safe haven for the accomplishment of SDGs.

Synchronizing TP with the conventional SL theory is aimed at ensuring that as servant leaders, Muslims have obligations not only to the created(Egel \& Fry, 2017), but also to the Creator (Allah)(Al-Buraey, 2001; Beekun, 2012) and not to violate the rights of the created (Fontaine et al., 2017). TP confines on leaders the automatic moral responsibility of the earth and its inhabitants as shown in Figure 1. Hence, they become more ethical in the pursue of SDGs. Researchers (e.g., Ahmad et al., 2018; Lin et al., 2019; Mayer et al., 2012) contend that an ethical perspective of power predisposes leaders to mobilize energy and resources for the collective good of everyone without nepotism.

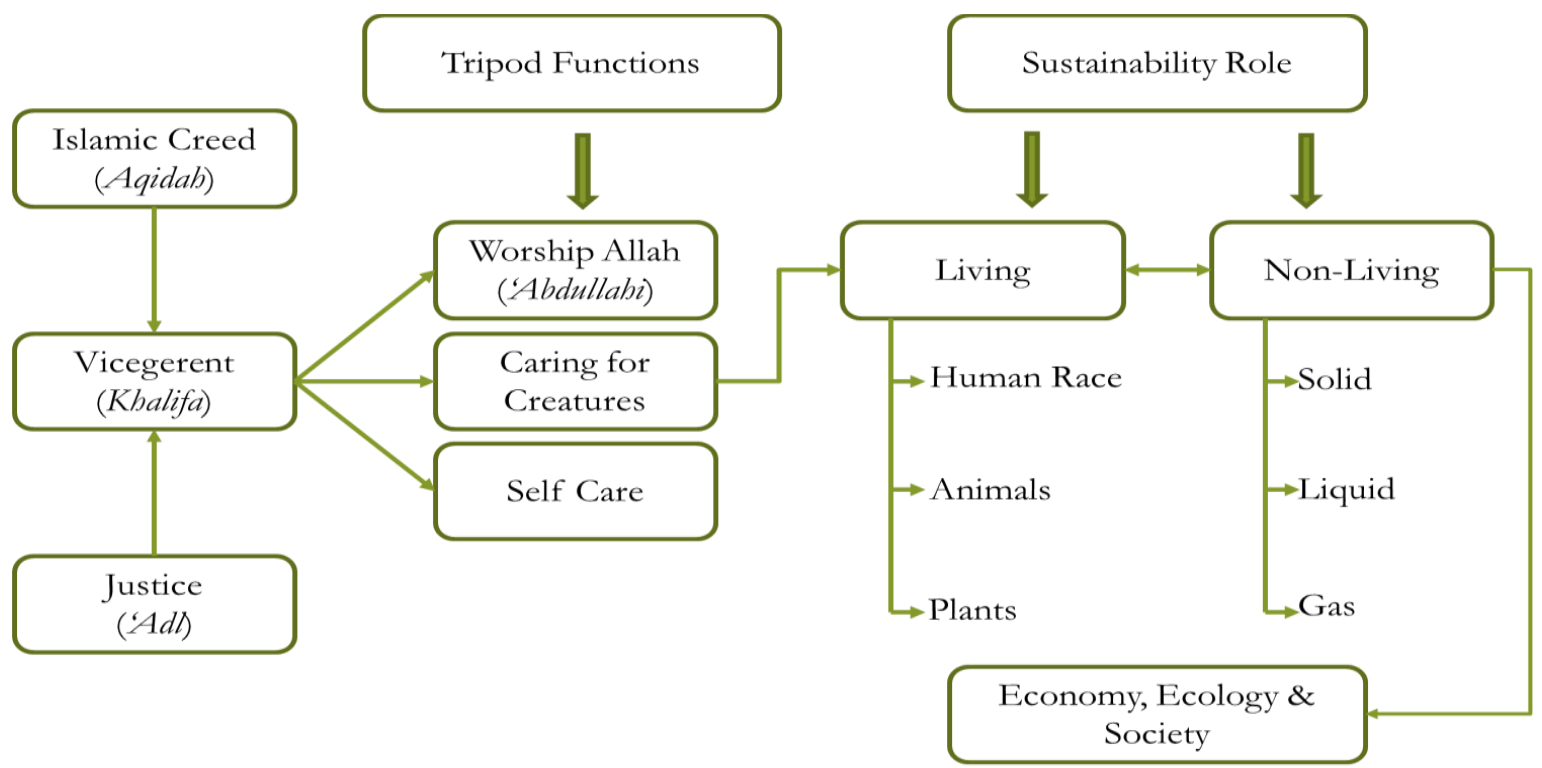

Figure 1. Tawhidic Paradigm Tripod Functions for Sustainable Development Source: (Authors)

Figure 1 depicts a Tawhidic flowchart of a servant leader (Khalifa) with responsibilities to the Creator (Allah), creatures, and self. Theoretically, the flowchart sets out Islamic SL 
differently from the conventional. Practically, it spells out leadership functions as they are related to attaining SD. In view of this, Muslims may better carryout SDGs. This paper posits that the crisis of SD is a crisis of disconnection between us and the Divine source. Individuals have been engulfed with self-unawareness, let alone our duties in the environment. Hence, the persistent and continued imbalance in the world.To this end, re-examining the conventional SL theory viz-a-viz TP will be excellent to change the course of human evolution in meeting SDGs.

\section{METHOD}

\section{Measure}

The paper adapted a constructivist grounded theory method (GTM) of Charmaz (2006). GTM is a method of theory construction in which researchers systematically develop a theory from collected data (Charmaz \& Bryant, 2011). In alignment with TP, an IPI-5es principles was developed building on Greenleaf's (1977) SL theory. This paper is not an exemption but extension of the conventional SL theory propositions.

\section{Participants}

Through purposive sampling, 5 Muslim managers, averagely aged 37years, having between 5 to 10 years working experience were sampled. Table 1 shows brief information about the participants.

Table 1. Participants' Brief Profile

\begin{tabular}{|l|l|l|}
\hline Code & Official Designation & Industry Type \\
\hline PS1 & Chief Analytics Officer & IT firm \\
\hline PS2 & Senior Administration Manager & Steel and Construction firm \\
\hline PS3 & Associates & Legal services \\
\hline PS4 & Senior Manager (Debt recovery) & Corporate banking \\
\hline PS5 & General Manager (Safety Department) & Oil and gas industry \\
\hline
\end{tabular}

\section{Research Procedure}

The procedure includes field entry methodology, data sources and collections techniques, data analysis techniques, the validation procedures, and storing of data.

\section{Entry into the Field}

Prior to field entry, participants were pre-informed through a letter of invitation on the purpose of the research. The letter avails participants to choose theirconvenient venue and time for the interview. All participants agreed to be interviewed.To avoid ethical issues (Creswell, 2013), they were asked to sign informed consent letters before the interview began.

\section{Data Source and Collection Instruments}

Charmaz and Bryant (2011 p.298) posit that "GTM may be used with varied types of data including ethnographic materials, documents and interview. Delamont (2004) argued that in qualitative studies, the main instrument is the researcher who may choose to observe, take notes, talk to people, and so forth. Hence, good researcher needs three skills: technical 
competence, interactive competence and; attention and steering competence (Gubrium \& Holstein, 2003).

This paper used three data instruments; personal interview, focus group (theoretical sampling) and documentary sources. Personal interview was employed to get primary data. Participants were engaged in a 40-60 minutes in-depth, semi-structured interview at their convenient locations. An adequate recording procedure (audiotape) was maintained during the interview. Interview protocol forms were handy for note taking. According to recommendations on theoretical sampling (Strauss and Corbin 1998), two participants later became co-analyst / focus group to clarify and validate arising issues during opening and axial coding process. Secondary data sources include Quran and Hadith, journals and textbooks.

\section{Data Analysis Technique}

Data collected were analysed in three stages of coding: open coding, axial coding and selective coding. The analytical process began with open coding. The study data consisted of over 220 minutesof audiotapes, which documented more than 180 minutes of interviews and 30 minutes of follow-up interaction with participants over a period of 35 days. All of the audiotapes were transcribed using intelligent verbatim method. Data were examined line by line in order to identify participants' thoughts in relation to the study's objective. With the aid of analytic memos, the Islamic terminologies used by participants enriched the data corpus and were later used for cross-referencing emerging codes and themes until a point of saturation was achieved.

Next was axial coding. Strauss and Corbin's(1990) 'coding paradigm' was adapted to make connections between identified themes and their subcategories. Finally, selective coding was done to systematically select and fill data into related core categories.

Strauss (1987) criteria used to identify core categories (i.e., Islamic themes selecting) include:

1. The centrality of a construct to other constructs.

2. The frequency of occurrence of a construct in the data collected.

3. The clarity of a construct based on the objective of the study.

4. The relationship (correlation) that co-exist between the constructs.

5. The possibility of a construct leading to the emergence of new theory.

\section{Validation and Reliability}

Validation was done through disconfirming evidence (Erickson, 1986), peer-review with two participants (Lincoln \& Guba, 1985), fiscal audit and triangulation (Angen, 2000; Creswell, 2013; Eisner, 1991). To ensure reliability, a good-quality audio tape was used with detailed fieldnotes which enhanced the transcribing and coding process.

\section{Safe keeping the Data Collected}

Confidentiality of data was maintained as stated in the informed consent letter. 


\section{Data Analysis and Findings Coding}

The interview data was transcribed and analysed. Outcome of emerging themes are presented as follows:

Question 1: What differentiate Islamic SL from Conventional SL

\begin{tabular}{|c|c|c|c|}
\hline $\mathrm{S} / \mathrm{N}$ & PS & Responses & Emerging Themes \\
\hline \multirow[t]{2}{*}{1} & PS1 & $\begin{array}{l}\text { Conventional leaders will often do things for their personal or } \\
\text { organization gains only }\end{array}$ & \multirow{2}{*}{$\begin{array}{l}\text { Conventional SL } \\
\text { Personal, } \\
\text { organizational or } \\
\text { societal gains alone }\end{array}$} \\
\hline & PS3 & $\begin{array}{l}\text { For me }[\ldots] \text { conventional leaders respond to things from the vantage } \\
\text { point of how it relates to and will affect them personally }\end{array}$ & \\
\hline \multirow[t]{4}{*}{2} & PS1 & $\begin{array}{l}{[\ldots] \text { as Muslim managers I will be answerable for my deeds to Allah }} \\
{[\ldots] \text { so, I think this is the difference }}\end{array}$ & \multirow{4}{*}{$\begin{array}{c}\text { Islamic SL } \\
\text { Allah, personal, } \\
\text { business, employee, } \\
\text { societal, and } \\
\text { community }\end{array}$} \\
\hline & PS2 & $\begin{array}{l}\text { To be a true servant leader, you owe a duty to your Creator, yourself, } \\
\text { employees, community [...] you must avoid biasness, self- } \\
\text { absorption, selfishness and narcissism to be distinct. }\end{array}$ & \\
\hline & PS4 & $\begin{array}{l}\text { An ideal leader considers the whole, considers cause and effect, and } \\
\text { considers consequences }[\ldots] \text { the whole, I mean, my duty to Allah, } \\
\text { my employees... this is being a servant leader }\end{array}$ & \\
\hline & PS5 & $\begin{array}{l}\text { Apart from the company's rules and regulation on moral disposition, } \\
\text { I do consider the impact of my words, actions and decisions, even on } \\
\text { people who may not be directly affected by my action ... so, I must } \\
\text { ensure fairness, equity, honesty and maintain high integrity }\end{array}$ & \\
\hline
\end{tabular}

Question 2: What Informed your Concept of Islamic Leadership

\begin{tabular}{|c|c|c|c|}
\hline $\mathrm{S} / \mathrm{N}$ & PS & Responses & Emerging Themes \\
\hline \multirow[t]{3}{*}{1} & PS1 & $\begin{array}{l}\text { My post is a trust from Allah, and I have a duty to act according to } \\
\text { that trust }\end{array}$ & \multirow{3}{*}{$\begin{array}{l}\text { Conscious self- } \\
\text { awareness of being } \\
\text { Muslims }\end{array}$} \\
\hline & PS3 & Knowing ourselves is key to improving ourselves. & \\
\hline & PS4 & $\begin{array}{l}{[\ldots] \text { fulfilling my duties and responsibilities as a Muslim makes me }} \\
\text { better and closer to Allah. }\end{array}$ & \\
\hline \multirow[t]{3}{*}{2} & PS1 & $\begin{array}{l}\text { Management and employees are all bond by the spirit of brotherhood } \\
\text { as was in the past. }\end{array}$ & \multirow{3}{*}{$\begin{array}{c}\text { Inspirations from how } \\
\text { early Muslims (i.e., } \\
\text { Prophetic era) ruled } \\
\text { and governed each } \\
\text { other }\end{array}$} \\
\hline & PS2 & [...] everyone has a moral role to revive the early Islamic era. & \\
\hline & PS4 & $\begin{array}{l}\text { Need for Muslim leaders to re-direct organizational policies and } \\
\text { practices through the Islamic divine laws - Shariah. }\end{array}$ & \\
\hline \multirow[t]{2}{*}{3} & PS1 & $\begin{array}{l}\text { Management from an Islamic perspective helps in the process of } \\
\text { rationalising limited resources optimally for the good of everyone. }\end{array}$ & \multirow{2}{*}{$\begin{array}{l}\text { Effective for problem } \\
\text { solving }\end{array}$} \\
\hline & PS5 & Efficient and effective management of resources & \\
\hline
\end{tabular}

Question 3: What Should be the Guiding Values IPI

\begin{tabular}{|c|c|c|c|}
\hline $\mathrm{S} / \mathrm{N}$ & PS & Responses & Emerging Themes \\
\hline \multirow[t]{3}{*}{1} & PS1 & $\begin{array}{l}\text { The feelings of 'Aqidah makes me more sincere at my work [...] I } \\
\text { cannot live in denial of my innate conviction }\end{array}$ & \multirow{3}{*}{$\frac{\text { Aqidah }}{\text { (Islamic Creed) }}$} \\
\hline & PS2 & $\begin{array}{l}{[\ldots] \text { in fact, as general principles in my workplace; modesty and }} \\
\text { humility are influenced by your commitment to the Islamic Creed } \\
\text { ('Aqidah) }\end{array}$ & \\
\hline & PS4 & $\begin{array}{l}\text { For us as Muslims, our belief should be strongly rooted in the } \\
\text { Supremacy of Allah over all things, though I am the manager, I must } \\
\text { humble myself in my dealings [...] you know, my belief and practice }\end{array}$ & \\
\hline
\end{tabular}




\begin{tabular}{|c|c|c|c|}
\hline & & constitute fundamental criteria with which people judge me & \\
\hline \multirow[t]{3}{*}{2} & PS1-5 & $\begin{array}{l}\text { Roles and duties are responsibilities enjoined on us by Allah, as His } \\
\text { Khalifa (vicegerent, successor, representatives) }\end{array}$ & \multirow{3}{*}{$\begin{array}{c}\text { Khalifa } \text { (Vicegerent) } \\
\text { Include all types of } \\
\text { leadership e.g., } \\
\text { political leaders, } \\
\text { spiritual leaders, } \\
\text { managers, } \\
\text { community leader } \\
\text { etc. }\end{array}$} \\
\hline & PS1 & $\begin{array}{l}{[\ldots] \text { as Muslims, you cannot shy away from your divine role as }} \\
\text { vicegerents ... more so, Quran and Sunnah remain our guiding } \\
\text { principles while carrying out any leadership function. }\end{array}$ & \\
\hline & PS3 & $\begin{array}{l}{[\ldots] \text { though, I am not the Head-of-state or president }[\ldots] \text {, but as }} \\
\text { Muslims, wherever you head, know that you are representing your } \\
\text { Creator }[\ldots] \text { so, in my workplace, I am one }\end{array}$ & \\
\hline \multirow[t]{4}{*}{3} & PS1 & $\begin{array}{l}\text { Justice in Islam knows no nobility [...], no scared cows, every } \\
\text { employee is assessed on a level playing ground when Tawhidic } \\
\text { paradigm is implemented }\end{array}$ & \multirow{4}{*}{$\begin{array}{c}\frac{\text { Adl (Justice) }}{\text { Loyalty, }} \\
\text { organizational / } \\
\text { society unity, peace } \\
\text { and love }\end{array}$} \\
\hline & PS2 & $\begin{array}{l}{[\ldots] \text { there are situations where I have had to give verdict against }} \\
\text { senior executives in favour of junior officers }[\ldots] \text { if this is well } \\
\text { handled by the HRM department, it will not spell doom. [...] it is the } \\
\text { Prophetic way. }\end{array}$ & \\
\hline & PS4 & $\begin{array}{l}\text { To unite your employees, just deal fairly amongst them }[\ldots] \text { it will } \\
\text { even earn you loyalty and respect }\end{array}$ & \\
\hline & PS5 & $\begin{array}{l}\text { every manager must keep this principle ( } A d l \text { ) at any means in order } \\
\text { to direct the affairs of the organization peacefully }\end{array}$ & \\
\hline
\end{tabular}

Question 4: Can Muslims Fear better on Sustainability

\begin{tabular}{|l|l|l|l}
\hline PS1-5 & Yes & It is divine, moral responsibility to take care of earth and its inhabitants
\end{tabular}

Question 5: What principles should a Muslim Servant Leader Possess

\begin{tabular}{|c|l|l|l|}
\hline S/N & Participants & Responses & IPI 5es Principles \\
\hline \multirow{3}{*}{1} & PS1, PS5 & Sabr (Patient), Foresight, Visionary, Shurah (Listening) & \multirow{2}{*}{ Expertise } \\
\cline { 2 - 4 } & PS3 & Humility, Ihitisab (Accountability) & \\
\cline { 2 - 4 } & PS4 & Shukr (Thankfulness), Respectful & \multirow{2}{*}{ Ethereal } \\
\hline \multirow{2}{*}{2} & PS1-5 & $\begin{array}{l}\text { Aqidah(Islamic Creed), Sodiq (Truthfullnes), Bir (Piety), } \\
\text { Tawakul (Reliance on Allah) }\end{array}$ & \multirow{2}{*}{ Ethical } \\
\hline \multirow{2}{*}{3} & PS2 & Compassionate, Altruism & \multirow{2}{*}{ Empowering } \\
\cline { 2 - 4 } & PS3, PS4 & Empathy, Tolerant, welfarism & \\
\hline \multirow{2}{*}{5} & PS1 - 5 & 'Adl(Just), Aklaq(morality), Honesty & Community growth, Freedom of Expression, Liberation \\
\cline { 2 - 4 } & PS2, PS4 & Khalifah(Vicegerent), Socially Responsible &
\end{tabular}

\section{Interpretations of Data Outcome}

Outcome of question 1 revealed that Islamic SL differs from conventional SL. From question 2, it could be inferred that Muslims leaders areself-conscious and inspired by the leadership success in the Prophetic era. Responses from question 3 indicated that leaders believed that their activities should be dependent on Tawhidic paradigm. Hence, the outcome from questions 5, produced an IPI-5es principles. These are supposed principles for Islamic SL. The outcome is not different from previous related studies on Islamic leadership (e.g., AlBuraey, 2001; Bhatti et al., 2016; Egel \& Fry, 2017; Fontaine et al., 2017; Khaliq \& Ogunsola, 2011; Ogunsola, 2018; Osman-Gani, Hashim, \& Ismail, 2013; Sarif, 2014). 


\section{DISCUSSION}

Based on information from the data analysed, IPI-5es principles model was developed for SL. Expertise Principles: These are exoteric values such as patient (sabr), humility, thankfulness (shukr), listening, foresight etc. Majority of these principles are also found in conventional SL theory. Ethereal Principles: They are Tawhidic derived principles that differentiate Islamic SL from conventional SL. They are known as esoteric principles. E.g., Tawhid (Islamic Creed), sodiq (truthfulness), 'amanat(trust) and so forth. In a comment by PS2 "seeking the pleasure of Allah in daily dealings with the employees, contributes towards uniting them while working in a friendly environment." So, esoteric principles avail leaders to perform dual functions - maintain vertical relationship with Allah and horizontal relationship with co-individuals (employees, followers or community).

Emotional Principles: These principles build bonds between the leader and the led.PS5 said "attending to the welfare of my subordinates builds a psychological contract between me and them." Examples of these principles include compassion (Rahim), empathy, altruism etc. Conventional SL theory also shares some of these principles.

Ethical Principles: They are universally expected principles from servant leaders. Islam places more premium on them e.g., 'Adl (Just), Aklaq (moral disposition) and so forth. PS3 commented "my authority is limited to what Islam permits me as a leader to do, it is a trust and I must render it back." Leaders who imbibe these principles will most likely not comprise their leadership trust for selfish desires. Empowering Principles: Principle such as Khalifah(Vicegerent) prompt leaders to be socially responsible. PS4 remarked that "Islamic leadership is positioned to solve the problems of humanity and provide a guide towards eternal betterment in this world and hereafter" They are principles that predispose the leaders to engender positive development within the society. Hence, leaders assume the role of the protector of the environment and its resources.

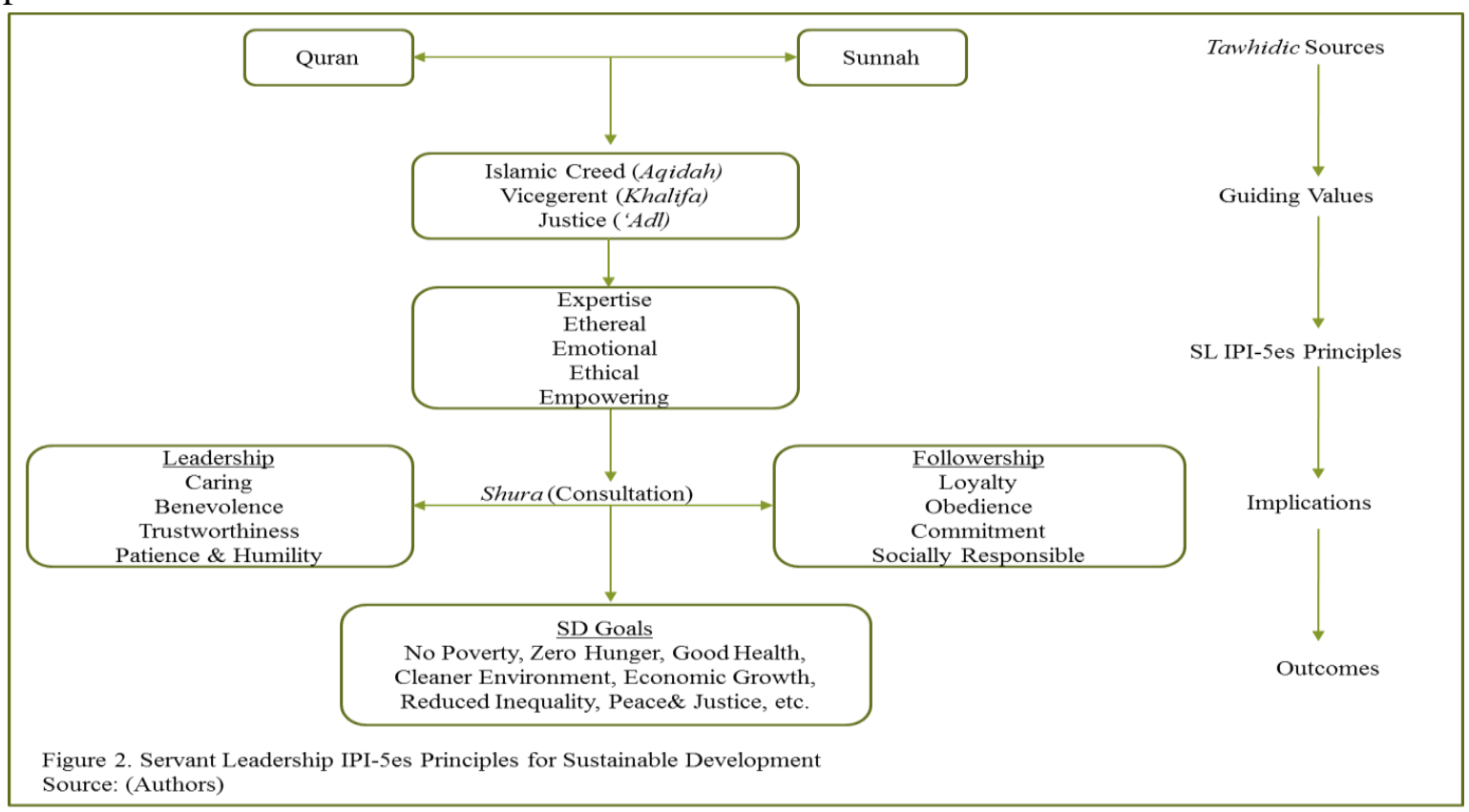

As shown in Figure 2, the IPI-5es principles portend an all-inclusive SL theory that combines both mundane and spiritual functions. Researchers (e.g, Barbuto \& Wheeler, 2006; 
Mottahedeh, 2001)assent that leadership functions are divine. Therefore, leadership represents a sense of mission involving the commitment to carry out the message of faith.

History showed that companies run by management with divine consciousness ('Taqwa), moral conscience ('Aklaq) and an awareness of social responsibilities have usually fared well(Al-Olaqi, 2015; Bhatti et al., 2016; Noor, 2002), while those preoccupied only with material rewards for their management and shareholders have seldomly being able to sustain their business in the long term (McCuddy \& Pirie, 2007). Therefore, the IPI-5es principles are considered as empowerment tools, which enables people (servant-leaders) to use their talents, skills and knowledge to set out standards that defines institutional missions, and fashion out acceptable (halal) means by which to realize such missions.

In the light of SD, taking the IP1-5es principles as key performance indicator (KPI) would tend to improve the achievement of SDGs as shown in Figure 2. Leaders imbued with the principles tend to curb vices such as societal / organizational sabotage, pilfering, embezzlement, theft, fraud, deliberate absenteeism, deliberate damage to nature / properties, and so forth. etc. More importantly, the principles can help prevent white-collar crimes; Gottschalk and Tcherni-buzzeo (2016) defined whit-collar crime as vices committed by members of the privileged socioeconomic (respectable) class e.g. accountants manipulating balance sheets to avoid taxes, procurement managers approving fake invoices for personal gain, online property crime etc.

\section{CONCLUSION}

Servant leadership is proposed has the leadership theory which may improve the performance of leaders to achieving SGDs. However, the current SL theory (Greenleaf, 1977) needed to be extended to accommodate spiritual values. Hence, the development of the IPI5es principles. In Islam, servant leaders should maintain vertical relationship with God (Allah) through worship and horizontal relationship with the environment (people, nature, and other creatures) in order to achieve success (Falah). The IPI-5es principles are not alien to the narrations of Prophet Muhammed (s.a.w): "Whoever wishes to be delivered from the fire and enter the Garden, should die with faith in Allah and the Last Day and should treat the people as he wishes to be treated by them." Sahih Muslim [Book 20, Number 4546].

The relevance of the IPI-5es principles cannot be underestimated, its Tawhidic philosophy are both physical in act and verbal in thought. So, if properly understood and administered alongside SD, the world is sure to build a brotherhood system that caters for the needs of the present without compromising the ability of future generations to meet their own needs. This is what sustainable development enlist.

\section{Implication of IPI-5es Principles for Sustainable Development}

The implications of the IP1-5es principles are both for the leaders and followers (subjects). On the one hand, leaders are predisposed to exhibit care, patience, visionary, trustworthiness, benevolence, engage in constant mutual consultation before taking decision, ensure peaceful co-existence and maintain friendly relations amongst subordinates. Their 
responsibilities also include breeding an atmosphere of love and respect to establish a universal brotherhood system.

On the other hand, followers are obliged to obedient, dedicated, loyal and commitment to community growth. They must be seen as socially responsible (not destroying assets or properties) and be good ambassador of the society. Above all, they should always provide sincere feedback (Ad-Deen-Naseeha) to leaders knowing fully well that they will account for their utterances with Allah. Taken together, these implications lead to mutual achievement of SDGs as shown in Figure 2.

\section{Significance of the Study}

Firstly, the study contributes theoretically to existing body of knowledge on spirituality and management from the Tawhidic paradigm. Secondly, itenablesleadersto form policies that accommodate spiritual virtues that drives a Shariah-compliance resource management. Thirdly, its practically creates sustained Ibadahic society where every act to achieving SDGs is exclusively to gain the pleasure of Allah.

\section{Limitation of the Study}

The study limited by fewer GTM studies on Islamic SL. Also, the interpretation of Islamic constructs is limited to the extent of the researchers' knowledge, skills and available resources.

\section{Area of Future Research}

Future study may conduct a time series analysis on servant leaders imbued with IPI-5es principles in order to determine SDGs success rate.

\section{REFERENCES}

Ahmad, I., Donia, M. B. L., Khan, A., \& Waris, M. (2018). Do as I say and do as I do? The mediating role of psychological contract fulfillment in the relationship between ethical leadership and employee extra-role performance. Personnel Review. https://doi.org/10.1108/PR-12-2016-0325

Al-Attas, S. ., \& Daud, W. . (2007). The ICLIF Leadership Competency Model (LCM): An Islamic alternative. Malaysia: IBFIM (763075-W) Publishers. Retrieved from www.ibfim.com

Al-Buraey, M. A. (2001). The Islamic model of administration: Strategy, implementation and implications. Managerial Finance, 27(10/11), 5-24. https://doi.org/10.1108/03074350110767556

Al-Olaqi, F. M. T. S. (2015). The Prophet Muhammad's leadership: An Islamic view. Advances in Social Sciences Research Journal, 2(9), 59-70.

Ali, A. J. (2009). Islamic perspectives on leadership: A model. International Journal of Islamic and Middle Eastern Finance and Management, 2(2), 160-180. https://doi.org/10.1108/17538390910965167

Alvesson, M., \& Einola, K. (2019). Warning for excessive positivity: Authentic leadership and other traps in leadership studies. The Leadership Quarterly, 30(4), 383-395. 
https://doi.org/10.1016/j.leaqua.2019.04.001

Alwazna, R. Y. (2016). Islamic Law: Its sources, interpretation and the translation of it into laws written in English. International Journal for the Semiotics of Law, 29(2), 251-260. https://doi.org/10.1007/s11196-016-9473-x

Angen, M. J. (2000). Evaluating interpretive inquiry: Reviewing the validity debate and opening the dialogue. Qualitative Health Research, 10, 1338 - 1352.

Antonakis, J., Bastardoz, N., Liu, Y., \& Schriesheim, C. A. (2014). What makes articles highly cited? The Leadership Quarterly, 25(1), 152-179. https://doi.org/10.1016/j.leaqua.2013.10.014

Atkisson, A. (2001). The Transformation of Globalization. Noetic Sciences Review, 57(16).

Bache, C. M. (2001). The Noetic core of sustainability: A response to Alan AtKisson's, "A quest for sustainability." IONS Review, 57, 18-21.

Bahauddin, K. (2018). The essence of leadership for achieving the sustainable development goals. Retrieved from https://sdg.iisd/commentary/generation-2030/the-essence-ofleadership-for-achieving-the-sustainable-developments-goals/

Barbuto, J. E. (JR), \& Wheeler, D. W. (2006). Scale development and construct clarification of servant leadership. Group \& Organization Management, 31(3), 300-326. https://doi.org/10.1177/1059601106287091

Bass, B. M. (2008). Bass \& Stogdill's Handbook of leadership theory, research and managerial applications (4th ed.). New York, NY: The Free Press.

Bedsworf, L. W., \& Hanak, E. (2010). Adaptation to climate change: A review of challenges and Tradeoffs in six areas. Journal of the American Planning Association, 76(4). https://doi.org/10.1080/01944363.2010.502047

Beekun, R. I. (2012). Character centered leadership: Muhammad (p) as an ethical role model for CEOs. Journal of Management Development, 31(10), 1003-1020. https://doi.org/10.1108/02621711211281799

Beekun, R. I., \& Badawi, J. (1999). Leadership: An Islamic perspective. Beltsville, USA: Amana Publications.

Bhatti, O. K., Alam, M. A., Hassan, A., \& Sulaiman, M. (2016). Islamic spirituality and social responsibility in curtailing the workplace deviance. Humanomics, 32(4), 405-417. https://doi.org/10.1108/H-03-2016-0022

Bowie, N. (2000). A Kantian theory of leadership. The Leadership \& Organization Development Journal, 21(4), 185-193.

Bruce, D. (2018). On philanthropy: U.N. Sustainable Development Goals falling short; how to apply an SDG lens to your giving. Retrieved from https://www.denverpost.com/2018/12/16/on-philanthropy-un-sdgs-fall-short/

Burns, H., Diamond-vaught, H., \& Bauman, C. (2015). Leadership for sustainability: theoretical foundations and pedagogical practices that foster change. International Journal of Leadership Studies, 9(1), 88-98.

Charmaz, K. (2006). Constructing Grounded Theory. London: Sage.

Charmaz, K., \& Bryant, A. (2011). Grounded theory and credibility. In Silverman, D (Eds.) Qualitative Research: Issues of Theory, Method and Practice (pp. 291-309). London: Sage.

Conger, J. A., \& Kanungo, R. N. (1987). Toward a behavioral theory of charismatic 
leadership in organizational settings. Academy of Management Review, 12(4), 637-647.

Cooper, J. F., \& Nirenberg, J. (2012). Leadership Effectiveness, Encyclopaedia of Leadership (Eds). CA: Thousand Oaks.

Creswell, J. W. (2013). Qualitative inquiry \& research design: Choosing among five approaches (3rd ed.). Thousand Oaks, CA: Sage Publications.

Dahl, A. L. (1996). Spiritual dimensions of sustainable development. Retrieved from https://bahai-library.com/dahl_spiritual_dimensions_development

Dartey-Baah, K. (2014). Effective leadership and sustainable development in Africa: is there “ really " a link? Journal of Global Responsibility, 5(2), 203-218. https://doi.org/10.1108/JGR-03-2014-0014

Delamont, S. (2004). Ethnography and participant observation. In Seale, C., Gobo, G., Gubrium, J. F., \& Silverman, D (Eds). Qualitative Research Practice. London: Sage.

Dennis, R. S., \& Bocarnea, M. (2005). Development of the servant leadership assessment instrument. Leadership \& Organization Development Journal, 26(8), 600-615. https://doi.org/10.1108/01437730510633692

Dinh, J. E., \& Lord, R. G. (2012). Implications of dispositional and process views of traits for individual difference research in leadership. The Leadership Quarterly, 23(4), 651-669. https://doi.org/10.1016/j.leaqua.2012.03.003

Dinh, J. E., Lord, R. G., Gardner, W. L., Meuser, J. D., Liden, R. C., \& Hu, J. (2013). Leadership theory and research in the new millennium: Current theoretical trends and changing perspectives. The Leadership Quarterly, 1-27. https://doi.org/10.1016/j.leaqua.2013.11.005

Egel, E. (2014). Islamic Leadership. In Blomme (Ed.), Leadership From Within (pp. 91-111). Macmillan Publishers Limited.

Egel, E., \& Fry, L. W. (2017). Spiritual leadership as a model for Islamic leadership. Public Integrity, 19(1), 77-95. https://doi.org/10.1080/10999922.2016.1200411

Eisner, E. W. (1991). The enlightened eye: Qualitative inquiry and the enhancement of educational practice. NY: Macmillan.

Emmons, R. A. (2000). Is spirituality an intelligence? motivation, cognition, and the psychology of ultimate concern. International Journal for the Psychology of Religion, 10(1), 3-26. https://doi.org/10.1207/S15327582IJPR1001_2

Erickson, F. (1986). Qualitative methods in research on teaching. In M. C. Wittrock (Ed.), Handbook of Research on Teaching. (pp. 119-161). NY: Macmillan.

Finn, D. (2009). Our uncertain future: can good planning create sustainable communities? Champaign-Urbana: University of Illinois.

Fitchett, J. R., \& Atun, R. (2014). Sustainable development goals and country-specifi c targets. Thelancet, 2(September). https://doi.org/10.1016/S2214-109X(14)70282-7

Fontaine, R., Khaliq, A., \& Oziev, G. (2017). Islamic leadership today. Kuala Lumpur: ICIFE, IIUM.

Freeman, G. (2011). Spirituality and servant leadership: A conceptual model and research proposal. Emerging Leadership Journeys, 4(1), 120-140.

Galli, A., Gordana, Đ., Hanscom, L., \& Kne, J. (2018). Think globally, act locally: Implementing the sustainable development goals in Montenegro. Environmental Science and Policy, 84(July), 159-169. https://doi.org/10.1016/j.envsci.2018.03.012 
Gardner, H. (1999). Intelligence reframed: Multiple intelligences for the new millenium. New York: Basic Books.

Gill, R. (2013). Theory and practice of leadership (2nd ed.). Sage Publications, Inc.

Gottschalk, P., \& Tcherni-buzzeo, M. (2016). Reasons for gaps in crime reporting: The case of white-collar criminals investigated by private fraud examiners in Norway. Deviant Behavior, 9625(July), 1-16. https://doi.org/10.1080/01639625.2016.1196993

Greenleaf, R. (1977). The Servant as Leader. In Servant Leadership (pp. 79-85). New York: Paulist Press, Inc. Retrieved from www.paulistpess.com

Gubrium, J. F., \& Holstein, J. A. (2003). Postmodern Interviewing. Thousand Oaks, CA: Sage.

Gupta, K., \& Agrawal, R. (2017). Sustainable development and spirituality: a critical analysis of GNH index. International Journal of Social Economics, 44(12), 1919-1939. https://doi.org/10.1108/IJSE-10-2015-0283

Hargreaves, A., \& Fink, D. (2003). The Seven Principles of sustainable leadership. Retrieved from https://jotamac.typepad.com/jotamacs_weblog/files/seven_principles.pdf

Hoch, J. E., Bommer, W. H., \& Dulebohn, J. H. (2016). Do ethical, authentic and servant leadership explain variance above and beyond transformational leadership? A metaanalysis. Journal of Management, $\quad$ XX $(\mathrm{X}), \quad 1-29$. https://doi.org/10.1177/0149206316665461

Ikerd, J. (2008). Sustainable capitalism: A matter of ethics and morality. Problems of Sustainable Development, 3(1), 13-22. Retrieved from https://ssrn.com/abstract=1483005

Ismail, A. G., \& Tohirin, A. (2010). Islamic law and finance. Humanomics, 26(3), 178-199. https://doi.org/10.1108/08288661011074954

Ismail, Y., \& Sarif, S. M. (2011). The Role of Tawhidic Paradigm in the Transformation of Management System. In Proceedings of the National Seminar on Islamic Management Systems Transformation (Trans-SPI) (pp. 127-147). Organized by Islamic Science University Malaysia (USIM), PWTC, Kuala Lumpur, 1-2 October. 1.

Jabnoun, N. (2008). Islam and management. Riyadh:International Islamic Publishing House.

Jeff, L., \& Tomicah, T. (2017). Why are the united nations' sustainable development goals stalling? Retrieved from https://psmag.com/environment/why-are-the-uns-sustainabledevelopment-goals-stalling

Judge, T. A., \& Piccolo, R. F. (2004). Transformational and transactional leadership: A metaanalytic test of their relative validity. Journal of Applied Psychology, 89(5), 755-768. https://doi.org/10.1037/0021-9010.89.5.755

Khaliq, A., \& Fontaine, R. (2013). Strategic management from an Islamic perspective: Text and cases. John Wiley \& Sons Singapore Pte. Ltd.

Khaliq, A., \& Ogunsola, O. K. (2011). An empirical assessment of Islamic leadership principles. International Journal of Commerce and Management, 21(3), 291-318. https://doi.org/10.1108/10569211111165325

Kilpinen, M. S., \& Clarkson, P. J. (2009). Exploiting change impact analysis to support sustainability. In 7th Annual Conference on Systems Engineering Research 2009 (CSER 2009). Loughborough Univeristy. Retrieved from https://www.researchgate.net/profile/P_Clarkson/publication/252080764_Exploiting_Ch 
ange_Impact_Analysis_to_Support_Sustainability/links/5449ed4d0cf2f6388084d6d4/Ex ploiting-Change-Impact-Analysis-to-Support-Sustainability.pdf

Kim, S., Kim, K., \& Choi, Y. (2014). A literature review of servant leadership and criticism of advanced research. International Journal of Social, Behavoral, Educational, Economic, Business and Industrial Engineering, 8(4), 1154-1157.

King, D. B., \& DeCicco, T. L. (2009). A Viable model and self-report measure of spiritual intelligence. International Journal of Transpersonal Studies, 28(1), 68-85.

Kouzes, J., \& Posner, B. (2007). The leadership challenge: How to get extraordinary things done in organizations. San Francisco, CA: Jossey-Bass.

Kumar, S. (2017). Spirituality and sustainable development: A paradigm shift. Journal of Economic \& Social Development, XIII(1), 123-134.

Lin, C., Liu, N.-T., Chiu, C.-K., Chen, K., \& Lin, N. (2019). Modeling team performance from the perspective of politics and ethical leadership. Personnel Review, 48(5), 13571380. https://doi.org/10.1108/PR-07-2018-0277

Lincoln, Y. S., \& Guba, E. G. (1985). Naturalistic inquiry. Beverly Hills, CA: Sage.

Lynch, J. A., \& Friedman, H. H. (2013). Servant leader, spiritual leader: The case for convergence. Journal of Leadership, Accountability and Ethics, 10(2), 87-95.

Lynn, R., \& Kahle, E. G.-A. (2014). Communicating Sustainability for the Green Economy (Eds). New York: M.E. Sharpe.

Magee, L., Scerri, A., James, P., Thom, J. A., Padgham, L., Hickmott, S., ... Cahill, F. (2013). Reframing social sustainability reporting: towards an engaged approach. Environ Dev Sustain, 15, 225-243. https://doi.org/10.1007/s10668-012-9384-2

Martiskainen, M. (2017). The role of community leadership in the development of grassroots innovations. Environmental Innovation and Societal Transitions, 22, 78-89. https://doi.org/10.1016/j.eist.2016.05.002

Maslow, A. H. (1943). A theory of human motivation. Psychological Review, 50(4), 370396. https://doi.org/10.1037/h0054346

Mayer, D. M., Aquino, K., Greenbaum, R., \& Kuenzi, M. (2012). Who displays ethical leadership, and wht does it matters? An examination of antecedents and consequences of ethical leadership. Academy OfManagement Journal, 55(1), 151-171.

McCleskey, J. A. (2014). Situational, transformational and transactional leadership and leadership development. Journal of Business Studies Quarterly, 5(4), 117-130.

McCuddy, M. K., \& Pirie, W. L. (2007). Spirituality, stewardship , and financial decisionmaking: Toward a theory of intertemporal stewardship. Managerial Finance, 33(12), 957-969. https://doi.org/10.1108/03074350710831738

McShane, S. L., \& Von Glinow, M. A. (2008). Organizational behavior: Emerging realities for the workplace revolution (4th Ed). New York: McGraw-Hill.

Meuser, J. D., Gardner, W. L., Dinh, J. E., Hu, J., Liden, R. C., \& Lord, R. G. (2016). A network analysis of leadership theory: The infancy of integration. Journal of Management, XX(X), 1-30. https://doi.org/10.1177/0149206316647099

Mittal, R., \& Dorfman, P. W. (2012). Servant leadership across cultures. Journal of World Business, 47(4), 555-570. https://doi.org/10.1016/j.jwb.2012.01.009

Mottahedeh, R. (2001). Loyalty and leadership in an early Islamic society. London, New York: I. B Tauris Publishers. 
Mutalib, M. A., \& Razali, W. M. F. A. W. (2012). The concept of servant and Islamic leadership: a comparative analysis. In International Conference on Islamic Leadership-2 (ICIL) (pp. 228-245).

Nicholls, J. R. (1985). A new approach approach to situational leadership. Leadership \& Organization Development Journal, 6(4), 2-7.

Noor, I. (2002). Prophet Muhammad's leadership, the paragon of excellence. Altruistic management: A cross-application to modern management and leadership practice. Utusan Publications \& Distribution Sdn Bhd.

Northouse, P. G. (2013). Leadership: Theory and practice (6th ed.). Sage Publications, Inc.

Ogunsola, K. O. (2018). Servant leadership: Developing an Islamic performance appraisal instrument for Muslim managers. Malaysian Management Review, 53(1), 55-76.

Osman-Gani, A. M., Hashim, J., \& Ismail, Y. (2013). Establishing linkages between religiosity and spirituality on employee performance. Employee Relations, 35(4), 360376. https://doi.org/10.1108/ER-04-2012-0030

Pearce, D. W., \& Turner, R. . (2009). Economics of Natural Resources and the Environment. Baltimore: JHU Press.

Pietraszewski, D. (2019). The evolution of leadership: Leadership and followership as a solution to the problem of creating and executing successful coordination and cooperation enterprises. The Leadership Quarterly, (May), 1-14. https://doi.org/10.1016/j.leaqua.2019.05.006

Price, T. L. (2003). The ethics of authentic transformational leadership. The Leadership Quarterly, 14, 67-81.

Rafiki, A. (2020). Islamic leadership: Comparisons and Qualities. IntechOpen. https://doi.org/http://dx.doi.org/10.5772/57353

Rost, J. C. (1993). Leadership development in the new millennium. Journal of Leadership \& Organizational Studies, 1(91), 91-110. https://doi.org/10.1177/107179199300100109

Russell, R. F., \& Stone, A. G. (2002). A review of servant leadership attributes: developing a practical model. Leadership \& Organization Development Journal, 23(3), 145-157. https://doi.org/10.1108/01437730210424084

Salih, T. M. (2003). Sustainable economic development and the environment. International Journal of Social Economics, 30(1-2), 153-162. https://doi.org/10.1108/03068290310453655

Sarif, S. M. (2014). Tawhidic paradigm and organizational policy and strategy practices. South East Asia Journal of Contemporary Business, Economics and Law, 5(2), 28-35.

Sherman, R. O. (2019). The Case for servant leadership. Nurse Leader, 17(2), 86-87. https://doi.org/10.1016/j.mnl.2018.12.001

Slimane, M. (2012). Role and relationship between leadership and sustainable development to release social, human and cultural dimension. Procedia - Social and Behavioral Sciences, 41, 92-99. https://doi.org/10.1016/j.sbspro.2012.04.013

Spears, L. C. (1995). Reflections on Leadership: How Robert K. Greenleaf's Theory of Servant-leadership influenced today's top management thinkers. New York: Wiley.

Spears, L. C. (2002). Servant-leadership: A journey into the nature of legitimate power and greatness. Mahwah, NJ: Paulist Press.

Spoelstra, S., Butler, N., \& Delaney, H. (2016). Never let an academic crisis go to waste: 
Leadership studies in the wake of journal retractions. Leadership, O(0), 1-15. https://doi.org/10.1177/1742715016658215

Stillman, T. F., Fincham, F. D., Vohs, K. D., Lambert, N. M., \& Phillips, C. A. (2012). The material and immaterial in conflict: Spirituality reduces conspicuous consumption. Journal of Economic Psychology, 33(1), 1-7. https://doi.org/10.1016/j.joep.2011.08.012

Stogdill, R. M. (1975). The evolution of leadership theory. New York: Oxford.

Strauss, A. (1987). Qualitative analysis for social scientists. New York: Cambridge University Press.

Strauss, A., \& Corbin, J. (1990). Basics of qualitative research: Grounded Theory procedures and techniques. Thousand Oaks, CA: Sage.

Summerfield, M. R. (2014). Leadership: A simple definition. American Journal HealthSystem Pharmacists, 71(Feb), 251-253. https://doi.org/10.2146/ajhp130435

Ulluwishewa, R. (2014). Spirituality and sustainable development. UK: Palgrave Macmillan.

Van Dierendonck, D. (2011). Servant leadership: A review and synthesis. Journal of Management, 37(4), 1228-1261. https://doi.org/10.1177/0149206310380462

WCED. (1987). Report of the World Commission on Environment and Development: Our Common Future.

Retrieved

from https://sustainabledevelopment.un.org/content/documents/5987our-common-future.pdf

Whetstone, J. T. (2002). Personalism and moral leadership: The servant leader with a transforming vision. Business Ethics: A European Review, 11(4), 385-392.

Wulf, C., Werker, J., Zapp, P., Schreiber, A., Schlör, H., \& Kuckshinrichs, W. (2018). Sustainable development goals as a guideline for indicator selection in Life Cycle Sustainability Assessment. Procedia CIRP, 69(May), 59-65. https://doi.org/10.1016/j.procir.2017.11.144

Zelenika, I., \& Pearce, J. M. (2014). Innovation through collaboration: Scaling up solutions for sustainable development. Environ Dev Sustain, 1-18. https://doi.org/10.1007/s10668-014-9528-7

Zhao, H., \& Li, C. (2019). A computerized approach to understanding leadership research. The Leadership Quarterly, (71772171), 1-21. https://doi.org/10.1016/j.leaqua.2019.06.001

Zohar, D., \& Marshall, I. (2000). SQ-Spiritual Intelligence: The ultimate intelligence. London: Bloomsbury Publishing. 